\title{
AN APPROACH TO CUSTOMER TRUST IN THE PORTUGUeSe BANKING SYSTEM
}

\author{
António Cabeças, António Duarte Santos \\ CARS - Center for Economic Analysis of Social Regulation \\ Autonoma University of Lisbon
}

\begin{abstract}
Globalization, seen as a simultaneous transformation in economics, politics and culture, has led to more intense competition in different sectors of the economy. In the banking sector the analysis of customer satisfaction, loyalty and trust has been considered of great interest in recent years.

In this study, we analyse the development of bank customer satisfaction and loyalty and, with more detail, the development of customer trust, using the results of surveys carried out with relevant statistical samples in Portugal and, for the first time, we also extend this analysis to bank customers in Spain.
\end{abstract}

Scientific development, particularly in the field of behavioural economics, which includes many contributions from psychology and sociology, as well as in the field of neurology, which gave rise to neuroeconomics, allowed for the adaptation and change of traditional economic decision-making theories, based only on economic rationality, in the wake of the Cartesian dualism and Newtonian atomism, allowing for a better understanding of decision-making It has been demonstrated in previous studies that the currently most relevant element for customer approval and loyalty to their main banking institution in Portugal is trust. Therefore, the growth or downward trend of these two variables will be a good indicator to understand the development of customer trust in banking evolution.

It has been verified that customer trust in banking and in the development of banks in the last years is not as negative as could be expected, considering all the problems that have affected this sector, mainly in Portugal. However, customer satisfaction has been declining over the past two years.

A significant change in the banking activity is taking place, a different approach has been implemented, and this change may lead to a decline in customer trust.

\section{Keywords}

Banking, bank customer, customer satisfaction, customer loyalty, customer trust, behavioural economics.

\section{INTRODUCTION}

Scientific changes in the field of behavioural economics incorporate not only aspects of the cognitive system, known as the reflexive system, but also emotional, sentimental, biological and cultural factors that are part of the automatic system for explaining decision making in all spheres of life, which develops dynamically and always in situations of risk and uncertainty.

Expansion of scientific knowledge about decision-making has led to the reasoning that levels of customer satisfaction and trust in banks are determining factors in 
customer acquisition and loyalty, which result from cognitive and emotional systems. Changes in factors such as satisfaction and trust are influenced by changes in the behaviour of individuals and in their decisions; prognostications of macro-decisions are rarely achieved given the stochasticity of human behaviour, taking into consideration the lack of determinism that has typically been used as a prerequisite in studies to predict future developments which are based on historical data.

Keynes (1936) deepens the distinction proposed by Knight (1921) between risk and uncertainty. Risk is a situation in which the probability of future results can be obtained through the theory of probabilities and statistical inference, and uncertainty is a situation where the prediction of future results, their probabilities and economic impact are based only on subjective estimates.

Keynes (1936) further stresses the importance of uncertainty in the economic dynamics defining uncertainty as all the phenomena to which the calculation of probabilities cannot be applied, and economic agents end up following animal spirits.

Recent studies by several authors - such as Daniel Kahneman and Amos Tversky on behaviour, António Damásio and Antoine Bechara, George Loewenstein and Scott Rick on emotions in the economy, and Amartya Sen on the cultural component - allow us to state that emotional and cultural factors, in context, can structurally alter the trend of any economic variable based on human behaviour.

The economic crisis, which began in Portugal between 2007 and 2008, is strongly linked to speculative activities developed by banking, growing indebtedness of families and companies and high external obligations in Portugal, which led to a decrease in family income, both directly and through the increase and adding of taxes, originated greater concern with issues related with global banking regulation, calling into question the theory of efficient markets developed by Eugene Fama in 1970 (Donário et al., 2013).

Recently, during this period of crisis, we have observed the fall of important financial institutions as the Lehman Brothers, in the United States of America at 2008, and Banco Português de Negócios (BPN) in 2018, Banco Privado Português (BPP) in 2010, Banco Espírito Santo (BES) in 2014 and Banco Internacional do Funchal (BANIF) in 2015, in Portugal.

From an Economic perspective, evidence of the crisis is made visible in the GDP decreasing in Portugal and in Europe between 2008 and 2009, and the reduction of the savings rate between 2007 and 2008, the slowdown of individual indebtedness after 2007, the increase of interest rates on deposits and loans and the increase of unemployment rate between 2008 and 2012 in Portugal. Moreover, the Index of Economic Feeling of the Portuguese and in the Euro Zone decreased significantly between 2007 and 2009 as we may verify in figure 1 .

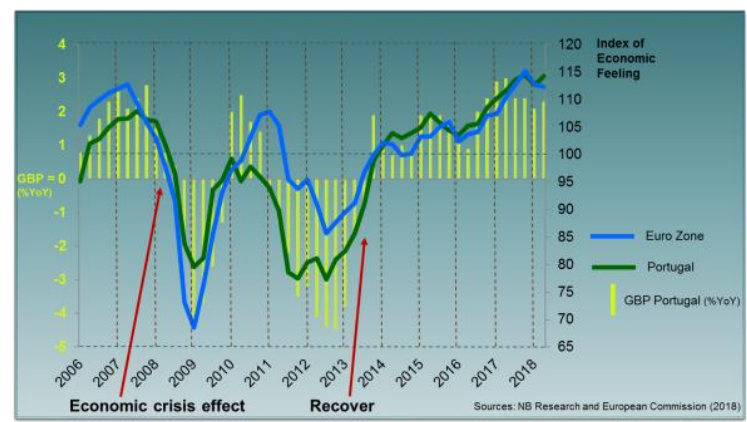

Figure 1 - Index of Economic Feeling (Euro Zone and Portugal)

\section{CUSTOMER TRUST}

To earn customer loyalty, the company needs to gain their trust (Oliver, 1999) and 
in the banking sector, trust is a key factor in the development of a long-term relationship between customer and bank (Crosby et al., 1990).

According to some authors, such as Cooper et al. (1988), trust is related to the risk perception that, in turn, is based on the greater or lesser level of optimism of individuals regarding the risk involved in their decisions, depending on the expected results to be perceived as losses or as gains, relative to a reference point (Kahneman et al., 1979; Kahneman, 2011).

The trust consists of an intangible attribute, integrating the endowment of individuals, reducing uncertainty in intersubjective relations, triggering the endowment effect (Thaler, 1981; Kahneman et al., 1991) that leads individuals to value more intensively the relationships they maintain with other individuals or institutions, namely the banks to which they are connected, this being a factor of customer loyalty. When the level of trust is high, transaction costs decrease, which leads to higher costs of change, due to the greater uncertainty and risk in relation to another bank, also leading to the loss of opportunities of other relationships (Yamagishi et al., 1998).

Several factors may lead the individual to remain in a given business relationship by re-establishing the relationship with a bank, even if it is not fully satisfied, and contributing to the maintenance of the status quo. This is due to transaction costs or transfer costs and to the psychological commitment to previous choices, even in the absence of risk aversion. Thus, following Samuelson et al. (1988), the status quo bias, which translates into the preference of individuals for the current situation, is an explanation for maintaining loyalty to a bank, despite the existence of some dissatisfaction with the service provided. According to these authors, rational models that ignored the status quo "will present excessively radical conclusions, exaggerating individuals' responses to changing economic variables and predicting greater instability than is observed in the world." (Samuelson et al.,
1988: 47-49). The preservation of the reference point is an option in many decisions, since risk aversion induces a bias that favours the maintenance of the status quo, that is, the reference point against which the change is compared to other options. In these decisions, the transfer cost is related to risk aversion, which implies the existence of risk and uncertainty, and that the cost (disutility) associated with the change exceeds the utility associated with the gain.

It is important to consider the set of qualities of the good, besides the pricequantity, which is one of the factors influencing the demand of the good or service by consumers (Silva, 1991: 133, Lancaster et al., 1966).

In the case of client-bank relationship, trust is also related to the branch, a place where the client has limited control regarding the employees, who may not act in the best interests of the client. And this issue arises, above all, due to transaction costs (material and non-equity costs) for the clients. A high level of trust, as already mentioned, reduces transaction costs between client-bank agent, the client not being motivated to move to another bank, thus leading to loyalty.

Coleman (1988) argued that any exchange, whether economic or social, involves an interaction between one or more people, and the result of this interaction generates a series of links, which, if they persist over time, will become resources for individuals, producing a stock of human or social capital.

The primary unifying element within social capital is trust, as this is the key factor in building a network of connections and commitments and is generated from action among individuals (Coleman, 1988).

For Anderson and Weitz (1989), considering the two parties involved, trust represents the belief of one party that, in the future, their needs will be met by actions undertaken by the other party.

We can understand the concept of trust when one of the parties believes that the 
service provider is reliable in delivering on its promises and that their needs will be met in the future (Dwyer et al., 1987; Anderson et al. al., 1994; Sirdeshmukh et al., 2002).

Clients who develop trust in service providers based on their experiences have good reason to stay in these relationships (Berry, 1995), since they present credibility and involve trust (Moorman et al., 1992).

Considering the two parties involved, trust represents the belief of one of the parties that, in the future, their needs will be met by actions undertaken by the other party (Anderson and Weitz, 1989) and trust exists when one party believes that the other party is whole and worthy of credibility, and lack of trust can pose a great threat to success (Bhattacherjee, 2002).

Trust is stronger when there is good communication between the parties and when partners avoid opportunistic behaviour that could harm one of the parties, especially those who share the same values (Morgan e Hunt, 1994). This is related to the perception of risk, which, in turn, is based on the greater or lesser level of optimism of individuals as to the risk involved in their decisions, depending on whether the expected results are perceived as losses or as gains (Cooper et al., 1988; Kahneman et al., 1979; Kahneman, 2011).

Berry (2002) stated that companies invest in long-term relationships not only to attract new customers, but also to keep their current customers and earn their loyalty. To win customer loyalty the company needs to gain their trust (Oliver, 1999), since the greater the trust, the greater the likelihood that the customer will do business with the company in the future and maintain a longterm relationship (Rich, 2000).

Trust functions as a vulnerability-reducing factor (Berry, 1995), since it contributes to the reduction of uncertainties and risks associated with the acquisition of goods and services (Ganesan, 1994).

According to Crosby et al. (1990), in the banking sector, trust is an essential factor for the development of a long-term relationship between the client and the bank. This requires a great deal of effort in the management of the relationship, especially when banking transactions with the customer are initiated (Adamson et al., 2003).

The greater the trust, the higher the probability of the client doing business with the company in the future and maintaining a long-lasting relationship (Rich 2000). Customers who develop trust in service providers, based on their experiences, have good reason to stay in these relationships (Berry, 1995). Companies invest in longterm relationships not only to attract new customers, but also to keep their current customers and earn their loyalty (Berry, 2002). To win the customer loyalty, the company needs to win their trust (Oliver, 1999).

The status quo bias, which translates into the preference of individuals for the current situation, is an explanation for maintaining loyalty towards a bank, despite the existence of some dissatisfaction with the service provided (Samuelson and Zeckhauser, 1988).

Keeping the status quo is an option in many decisions, since risk aversion induces a bias that favours maintaining the status quo (the benchmark against which change is compared) over other options (Silva, 1991; Lancaster et al., 1966).

Trust consists of an intangible, integrating the endowment of individuals, reducing uncertainty in intersubjective relations, triggering the endowment effect, which leads individuals to value their relationships with other individuals or institutions, banks with whom they are connected being a factor of customer loyalty (Thaler, 1980; Kahneman et al. 1991).

In the banking sector, trust is an essential factor for the development of a long-term relationship between the client and the bank (Crosby et al., 1990).

\section{STUDY METHODOLOGY}


In this study, we used consistent empirical models with economic theory, considering the most recent theoretical developments regarding the decisions of the individual in behavioural economics and studies related to neuroeconomics. The use of econometric models as dynamic models allows us to avoid the bias potentially caused by the omission of relevant variables, and capturing the adjustment of the dynamic process between the balance and the imbalance that characterizes the decisions of individuals.

The empirical study was carried out based on answers obtained from two online questionnaires applied to Portuguese bank customers, the first in 2014, with primary data of 498 valid responses considered (the same issues were referred to 2007 as the time before the financial crisis and to 2013 as a time of crisis) and the second questionnaire in 2019, with 387 valid responses, also used as primary data. We also used secondary data from European Customer Service Index (ECSI) 2017, Marktest BASEF, Annual macro-economic database of the European Commission's Directorate General for Economic and Financial Affairs (AMECO), Bank of Portugal, Portuguese National Statistics Institute (INE) and PORDATA from Francisco Manuel dos Santos Foundation.

Regarding the data obtained from the questionnaires, we verified the inter-item consistency of the items used by performing the Cronbach Alpha test in SPSS, which consists of analysing the correlation between the responses provided by the respondents.

Although there is no clear indication of what the ideal sample size should be, Anderson et al. (1988) consider acceptable a sample of 100 to 150 respondents (Crosby et al., 1990).

However, Hair et al. (2005) recommend at least 200 responses as the critical sample size, which should increase if there is suspicion of poor specification of the model used or if it is too complex.

Using statistical methodologies commonly used in this type of study, we have applied the formulas for calculating confidence intervals to determine the minimum size of a sample.

In a generic approach, if we consider an estimated sample proportion $\mathrm{p}$ of a binomial population, intending to obtain in the results of this research a confidence level of $95 \%$, considering a maximum error intended for the confidence interval of 5 percentage points, the sample must have a minimum of 385 responses.

This approach, widely used to establish the minimum desirable dimension of the sample, is adequate for the processing of sample proportion values, but in the case of this study, since we have 498 valid answers to the questionnaire used, we can calculate the values of the mean and standard deviation of the samples for the studied variables, because a Likert scale with possible values of 1 to 10 was used for most items of the questionnaire.

We can consider the formula for calculating the confidence interval for the mean of a normal population with observations number greater than thirty $(n>30)$ and unknown mean and standard deviation.

As the mean and standard deviation of the population are not known, we used the sample mean and its sample standard deviation $S_{x}$. The $Z(\alpha / 2)$ value of the normal distribution is 1.96 for a $95 \%$ confidence level, considering that the sample sizes used in this study are significant $(n>30)$. Thus, in this case, the sampling error can be calculated by the following formula:

$$
\varepsilon=\mathrm{Z}(\alpha / 2) \mathrm{S}_{\mathrm{x}} / \sqrt{ } \mathrm{n}
$$

The average margin of error of the sample collected in 2014 is 0.16 , considering all the questions were answered using a scale of 1 to 10 , with only two of the variables presenting a maximum error equal to 0.20 . For the 2019 study, the margin of error is 0.15 for all variables and 0.20 for the questions answered using a scale of 1 to 10 . According to the calculations made, we can assume that the samples obtained with 498 and 387 valid observations are adequate to obtain reliable and valid results in the analysis of the considered variables. 


\section{THE EVOLUTION OF CUSTOMER TRUST AND SATISFACTION: ANALYSIS OF RESULTS}

Considering ECSI 2017 data, we may state that customer trust decreased in the beginning of the economic crisis and continued until 2009 and there was a slight increase in 2012 and 2013, followed by another decrease in 2014, after the numbers remaining stable after that year (see Figure 2).

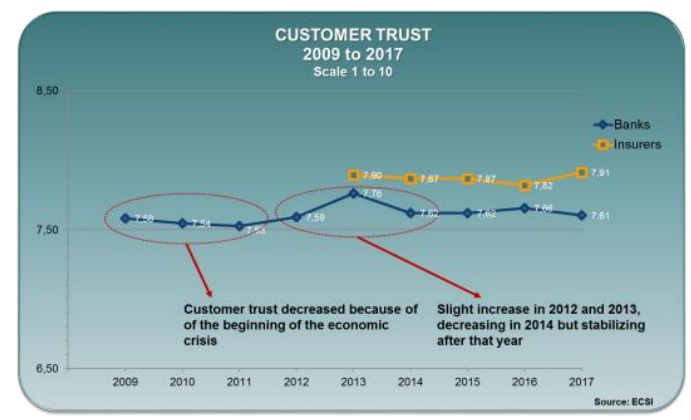

Figure 2 - Customer trust from 2009 to 2017 (ECSI 2017 - Global Results)

With Marktest BASEF 2017 data, we may also verify that the negative effect on trust of the economic crisis proves to be stronger in main retail banks in Portugal, except for the Portuguese public bank Caixa Geral de Depósitos (CGD) in which the beginning of the crisis had a positive effect, as we may verify in figure 3 .

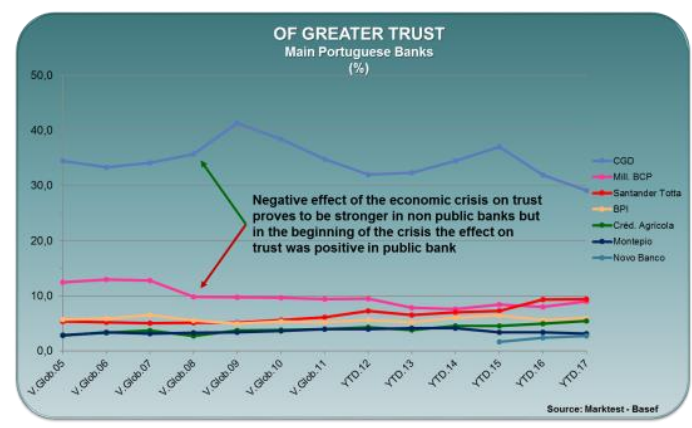

Figure 3 - Customer trust from 2005 to 2017 (Marktest BASEF)

In terms of customer satisfaction, using data form ECSI 2017, we may conclude that it continued to increase because of the improved quality of services provided by banks until 2014 and stabilized until 2016. Customer Satisfaction decreased in 2017 and the first data for 2018 confirm the downward trend observed in 2017, as we may verify in figure 4.

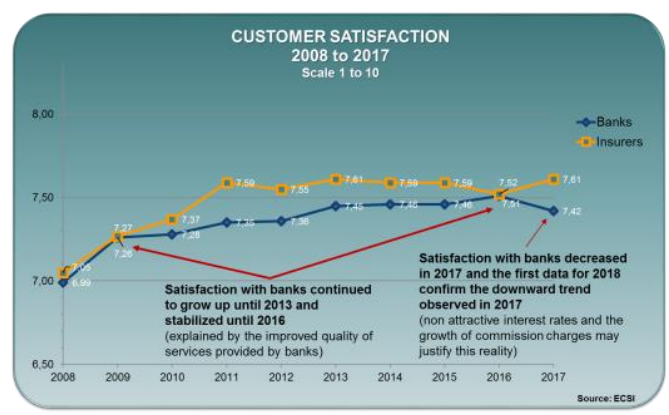

Figure 4 - Customer Satisfaction from 2008 to 2017 (ECSI 2017 - Global Results)

Based on Marktest BASEF 2017 data, we may conclude that despite the crisis period, customer satisfaction increased until 2014, the year of BES resolution, justified by the improvement in the quality of services provided by banks, as we may confirm in figure 5 .

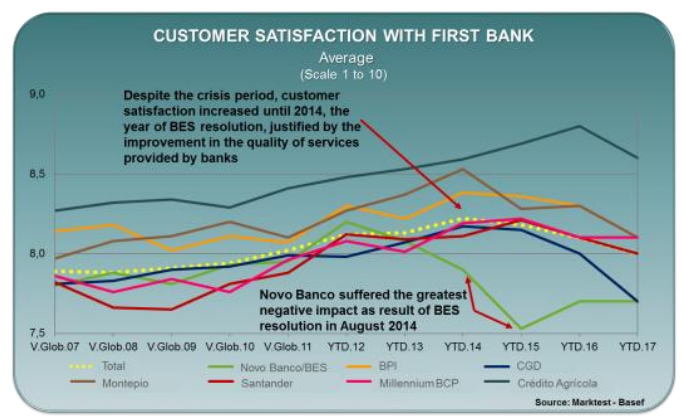

Figure 5 - Customer Satisfaction from 2008 to 2017 (ECSI 2017 - Global Results)

Portuguese customer satisfaction with banks decreased slightly in ECSI 2017, from 7.51 to 7.42 , on an evaluation scale from 1 to 10 , but it is higher than the global average of all other economic sectors, which was 7.29. The levels of satisfaction and loyalty decreased in 2017 but not significantly. We also may verify that customer satisfaction with Portuguese 
banks is comparable to that in other countries in Europe and in other continents. The results of ECSI 2017 show that the customer satisfaction index for banks is not lower than the average for other sectors of the economy. However, satisfaction with banks declined slightly compared to the previous year.

ECSI 2017 also states that the assessment of customer satisfaction with banks in Portugal is not very different from that in other countries in all continents.

The empirical study confirms that the financial crisis, which began in 2007/2008 in Portugal, influenced the behaviour of Portuguese banking customers in reducing savings and the volume of credit obtained from banks. It also influenced the decline in customer satisfaction, loyalty, and customer trust in relation to their main bank.

In addition to trust, clients' assessment of their bank's image has also lowered during the period of financial and economic crisis and loyalty has also decreased significantly, in regards to the likelihood of customers recommending their main bank to others.

At the start of the financial crisis, the ECSI (ISEGI, APQ and IPQ) and Marktest BASEF also show a decline in customer trust in Portuguese banks, with particular emphasis on private banks.

It is also evidenced that the emotional component, considered in the perspectives by Damásio et al. (2005) and Loewenstein et al. (2008), and the cultural component, according to Sen (2004), influenced the behaviour of bank clients in Portugal in evaluating their overall satisfaction and level of loyalty to their main bank in the period economic crisis. The variable that stands out the most is the trust oriented directly to the emotional perspective of the idea of the existence of a crisis. This can be seen in figure 6 .

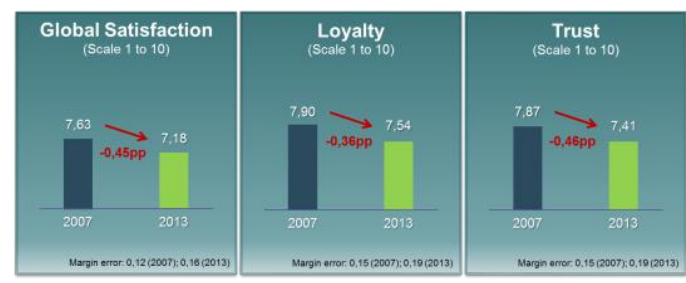

Figure 6 - Decrease of customer satisfaction, loyalty and trust during the crisis (Own elaboration)

In the same study, it was confirmed that the assessment of the image and trust lowered during the period of the economic crisis, with greater emphasis on the decrease in trust and loyalty, as did the likelihood of customers recommending their main bank to others.

At the beginning of the economic crisis, ECSI and Marktest BASEF also showed a decrease in Portuguese customers' trust in banks, with a greater emphasis on nonpublic banks.

As trust is the main factor for satisfaction, we can infer that the good results verified for Customers Satisfaction in previous years prove that Portuguese customers continue to trust banks. Yet, something is happening, because last year Customer Satisfaction Level decreased, which can be explained by the offer of unattractive fees, by the increase in commissions charged by banks, as a compensation for the decrease in the difference between active and passive interest rates. The use of new technologies has also influenced the decrease of direct personal contact with customers.

The decline in the level of satisfaction in 2017 can be explained by the lack of interest rates, given the recent international financial situation, by the increase in commissions charged by banks, as a compensation for the decrease in the difference between active and passive rates, and by the use of new technologies, which lead to less direct personal contact with customers.

These facts evidence a significant shift in the banking activity, a rather different approach. This means that the banking activity is changing, and this new way may lead to a further decline in customer trust and, as everything in life, trust will be crucial to ensure the future of banking.

Through the answers obtained in the questionnaire, we can identify the most relevant factors to guarantee customer 
satisfaction and loyalty, and this analysis was carried out through two complementary approaches.

The first one through the analysis of the direct answers of the clients that identified which factors they considered having gained more relevance for satisfaction and loyalty, and also those that they considered having lost relevance with the economic crisis. The second one, through the use of multiple regression models to identify the weightier factors contributing to customer satisfaction and loyalty.

From customer-perceived perceptions, the factors that have gained most relevance in contributing to satisfaction and loyalty during the period of the economic crisis were the clarity of the information provided, the price of the products and services offered, the problem-solving ability, and counselling of agents.

The choice of these factors as more relevant in a period of crisis allows us to confirm the importance of banks correctly informing their customers, who have become more sensitive to the price of banking products and services, and that problem solving and good advice of the products and services appropriate to the clients'.

In times of crisis, with fewer resources available to customers, applying resources correctly becomes more relevant.

The main factors that lose relevance during the economic crisis in the declarative way are the contact by the bank and the waiting time to be attended.

The choice of these factors by the clients shows that being contacted by the bank, from the perspective of proactive contact with the client, and the waiting time to be attended, become less importance.

This can be justified by the investment banks have made in the implementation of Customer Relationship Management (CRM) systems and, more recently, Customer Experience Management (CEM).

The valuation of customer trust in the period of crisis and the weight of this variable in the overall satisfaction of clients have both lowered.

According to the statements by customers, the factors that currently contribute most to loyalty are trust and compliance with deadlines by the bank, and the most important variable is trust. However, both customer valuation and the weight of this variable decreased in the period of economic crisis.

In the set of the two analyses carried out, both for global satisfaction and for loyalty, the most important variable in terms of importance in the two moments considered, before and during the economic crisis, is trust.

The importance of trust is made evident, as we have previously pointed out. in the fact that there is some uncertainty resulting from the economic situation of the country and that some banking institutions disappeared due to the crisis, confirming Berry's (1995) conclusion that clients who develop trust in service providers based on their experiences have good reason to stay in these relationships.

We also find that there is a greater requirement for the clarity of information provided by banks, a greater sensitivity to the price charged for their offer of banking products and services, a greater requirement for problem solving skills and a greater importance regarding banking advice.

We conclude that satisfaction is important to ensure customer loyalty, confirming Oliver (1999), who argues that satisfaction is one of the key concepts for earning loyalty, since loyalty does not exist without satisfaction.

\section{THE EFFECTS OF THE ANALYSIS AND THEORETICAL SUPPORT}

In this situation, we confirm that clients assess their trust level poorer when faced with the current economic crisis situation, given that, according to Perspective Theory, Kahneman et al. (1979), the effect of the expectations of losses becomes more intense, given its function to be convex, due to the decrease of disposable income that accentuates the disutility of any costs.

According to Kotler (2000), competition can bring down products and services very quickly, and the cost of attracting new customers to a company could be up to five 
times higher than the cost of retaining current customers. We confirm the hypothesis that, in times of economic crisis, attention must be paid to providing services and care for existing customers. This can be explained by the endowment effect and the consequent asymmetric assessment of the costs and benefits perceived by individuals.

Through the responses obtained in the questionnaire used for this study, considering the period of economic crisis, we confirm that the overall satisfaction of clients in regards to banks depends on the satisfaction with their service and that client loyalty and trust depend on their global satisfaction.

In our view, these relationships can be justified, since good service provided by banks is fundamental to guarantee a better quality of service and potentiate the increase of customer's satisfaction, which translates into the framing effect (Tversky et al.; 1981), - how the problem is presented affects decision.

On the other hand, customers who are satisfied and trusts their main bank tend to be more loyal because, if there are no other differentiating factors in the competition, such as a better price for products and services that might lead the customer to think of a prospect of utility, the client will not feel the need to change bank.

This result confirms Oliver's (1999) assertions that in order to achieve customer loyalty a company needs to be trusted. Rich (2000) believes that the greater the trust, the greater the ???? in the future, the client will be able to conduct business with the same company and maintain a long-term relationship.

As mentioned in the introduction, according to Crosby et al. (1990), trust in banking is an essential factor in the development of a long-term relation between the client and the bank. This connection requires a great deal of effort in managing the relationship, especially at the start of banking transactions with the customer (Adamson et al, 2003).

The economic models associated with decision-making are consequential by nature and assume that decision-makers choose alternatives for action, assessing the appropriateness and likelihood of their consequences, integrating this information through expectations based on calculations. The alternative chosen by a decision maker may not be the one that is most useful in the light of the neoclassical theory of utility, i.e., people's preferences for uncertain outcomes are represented by a function involving different variables, such as financial return, probability of occurrence, and risk aversion.

In this perspective, people with different assets, expectations and preferences have different points of reference and, therefore, their decisions vary. These decisions are affected by how the expected results are perceived. This theory of perspective (Kahneman et al., 1979) considers that investors do not act only from a rational point of view, according to the neoclassical theory, but the same decisions are influenced by emotional, biological and context factors.

We can also infer from the analysis of the results that the client, in times of economic and social crisis, is more sensitive to the usefulness of the price charged by banks for their products and services. In this perspective, he or she may become less loyal to their main bank due to considering that the marginal utility of a good increases with its reduction, along with the endowment effect.

According to Kotler (1998), perceived quality is one of the important factors to achieve customer satisfaction and is also a fundamental variable to guarantee their loyalty. A good quality service or product is a key factor in achieving customer loyalty.

We have also verified that the development of the image and assessment of customer trust in relation to their main bank decreased during the period of economic crisis, in particular, a decrease of trust.

Customer loyalty, the probability of repurchasing products and services offered btheir main bank, also declined significantly, as in 2007 the probability of customer repurchase was $76.7 \%$, having decreased 4 percentage points to $72.7 \%$. The same applies to the probability of 
customers recommending their main bank, which was $72.9 \%$ before the crisis and fell 4.2 percentage points to $68.6 \%$ in 2013 .

Customer trust in relation to their main bank is reduced in view of the crisis, which is obviously confirmed by the fact that banks have disappeared in recent years as a result of the crisis both at national and international level.

In terms of emotional expectation, we can conclude that customer trust in their main bank declines significantly before the crisis factor.

Moreover, trust in the Portuguese banking system in general is the variable with the lowest rating of all the variables analysed in this study, which evidences a rather pessimistic behaviour of the clients regarding their national banking system.

\section{CULTURAL AND BEHAVIORAL PERSPECTIVE}

Although some economists feel tempted by the idea that all human beings behave the same way, there is much evidence to indicate that this idea is not generalized and that cultural factors influence economic behaviour (Sen, 2004).

Cultural influences can cause a big difference in ethics, responsible behaviour, motivational spirit, dynamic management, entrepreneurship, risk-taking and a variety of other aspects of human behaviour that may be crucial to economic success (Sen, 2004).

Considering the role of cultural aspects in customer behaviour, the geographic areas of the north and south of Portugal, we can attest that the mean values of global satisfaction and customer loyalty values are higher in the northern part of the country. Through the $\chi^{2}$ adjustment test, we have confirmed that there are significant differences in customer behaviour in terms of loyalty, both in 2007 and 2013. In the case of satisfaction, this difference is only significant in 2007. This means that this difference in satisfaction is not so relevant in a period of economic crisis.
Considering that the difference obtained for customer loyalty in the two regions is higher than the margin of error of this study, we can conclude that there is evidence of the influence of the housing regions on the level of customer loyalty which, due to their own cultural factors, influence customer behaviour.

This behaviour has also been confirmed in the evaluation of global customer satisfaction, with better results in the northern region of Portugal, confirmed over the last years by the Marktest BASEF data, which shows higher evaluation in customer satisfaction in the north of the country when compared to the south.

Given that banks have focused on improving service quality and more even offer of products and services throughout the national territory, we can infer that the difference is due to cultural factors and not to differences in behaviour of banks in the north and in the south of the country.

In the analysis carried out in terms of education, we can conclude that clients with the highest levels of education, with masters or PhDs, are more demanding in the evaluation of their main bank.

Customers who are just satisfied are more willing to switch providers when a better offer comes up. Clients who are fully satisfied will be prone to change (Kotler et al., 1998). A very satisfied customer creates an emotional link, beyond rational preference, which provides consumer loyalty (Kotler et al., 1998). For customercentred companies, customer satisfaction is both a goal and a marketing tool. Companies that achieve high customer satisfaction rates make sure that their target market is aware of this (Kotler, 2000).

In these circumstances, understanding the client's concerns and anticipating any problems are very important. However, fixing faults that may exist will be paramount.

We can explain the decline of trust in banks by Portuguese customers in the economic crisis as related to a pessimistic behaviour. According to Perspective Theory (Kahneman et al., 1979) the effect of the loss of expectations becomes more intense 
due to its convex value function. Humans are unpredictable and often not consistent, and they are generally averse to increased risk and prone to losses and the decrease in disposable income accentuates the disutility of any costs.

Competition can topple products and services very quickly and the cost of attracting new customers to a company could be up to five times higher than the cost of retaining current customers (Kotler, 2000). This reality shows us how focusing on the relationship with existing customers is important, as well as improving the quality of products and services provided, as well as clearly stating the risk and evidencing more security in the offered products.

Satisfaction is important to ensure customer loyalty, as stated by Oliver (1999), who argues that satisfaction is one of the key concepts for earning loyalty, because loyalty does not exist without satisfaction. However, satisfaction is not the only element determining loyalty. Hennig-

Thurau et al. (2002) confirmed this fact, which had been previously mentioned by Reichheld (1994), Jones and Sasser (1995).

\section{TOPICS ON THE CHALLENGE OF CUSTOMERS' TRUST WITHIN THE DEADLINE: THE "FACE-TO-FACE" DILEMMA}

Clients are at the core of banking, which aims to meet their needs for financial services. These services are a means rather than an end, since clients hold the power. Any future banking model will not function if imposed to clients. There is no future for that type of model. Clients have tools at their disposal but the human element will continue to be decisive for trust enhancement. Millennials (those born between 1980 and 2000) are not the sole clients; there is a still a group of the population whose financial literacy is lower and whose habits are those of previous decades, both in European countries and in countries belonging to the
OECD (Banco de Portugal, 2016; Lisack et al, 2016. The more open and inclusive is a banking offer, the better conditions it creates for customer trust. We believe this interaction becomes increasingly distant, so the fact that banks are available, that they do not fail and the immaterial nature of the business, as well as the fact that clients are free to choose their path, makes communication channels crucial for banks to keep in touch with clients. The banking activity will continue but it will be less important in the future and it will not necessarily be conducted by banks. There are native digital clients and analogical clients. The challenge that banking has to face is to make the digital part of the lives of older or less digital clients (Guillemet 2018). There have different requirements and want to feel secure and confident in their choices. That confi- 
dence is brought by interacting with people that are physically present, with whom they can speak face-to-face. The segmentation of banking services will lead them to opt for specific bank. The banking sector will alter its structure in terms of client interaction: the account manager will become a specialized financial advisor who can act as intermediary in all types of operations and will not have to be physically close to clients. This banking advisor will not be the bank clerk as we know it today. That is the faceto-face dilemma.

The digital in the banking system started as a service provider that has no time or place restrictions. In Portugal, banks aim that a high number of clients use digital and mobile channels. However, the digital has implied structure costs that have a relevant impact on cost-to-income and banks now aim to lower that indicator. Clients do not want financial products and services whose risks are not visible at a time of economic growth but which can be serious in the future. However, through the app, clients may deposit or withdraw money at the entrance of their company or home. Scheduling the meeting is rather simple. A bank agent drives a car that has deposit and withdrawal capabilities, a service that assists shop owners. This is not fiction. Banks will offer more and more mobile services. This is true today and will continue to expand. The Polish bank, Idea Bank, founded in 2010 , offers this service and is highly success in Poland in view of its innovative nature, namely, mobile deposit service. Idea Bank clients are nowadays mainly business owners. In Portugal, Attico Bank, which belong to Millenium BCP, has now an extended schedule (it is open until 8 p.m.) and has optimized its branch network. Barclays Bank has provided its client managers with $\mathrm{XXX}$, allowing then to create new client accounts in fifteen minutes. These are all strategies to reduce the distance between banks and their clients, thus making clients aware of a new type of branch that will provide them with the services offered in traditional ones.

\section{CONCLUSIONS}

This empirical study has allowed us to conclude that the economic crisis, which started in Portugal between 2007 and 2008, influenced the behaviour of Portuguese banking customers, who decreased their savings and the amount of credit obtained in banks. We also confirm the decrease in customer satisfaction, in the level of customer loyalty and in trust in their main bank.

The emotional component, according to Damásio (2005) and Loewenstein et al., (2008), and the cultural component, according to Sen (2004), influence customer satisfaction, customer loyalty and customer trust in a period of economic crisis.

Regarding the cultural aspects of Portuguese customers' behaviour, there is evidence of differences due to geographical residence in terms of satisfaction assessment and customer loyalty. Satisfaction, trust and loyalty show better results in the north compared to the south of Portugal. Banks have invested in improving the quality of services, as well as on product and service offer is in the entire national territory which have had a positive impact on customer perception. Education is also important for customer satisfaction, trust and loyalty. The overall satisfaction, trust and loyalty of clients with higher levels of education are lower than of other customers. Customers with a higher level of education are also more demanding in their evaluation of their main bank.

The most relevant factors for loyalty in a period of economic crisis, based on explanatory regression models and sorted by relevance, are:

1. Customer Global Satisfaction

2. Customer Trust

3. Correct carrying out of orders

4. Quality of the offer

5. Meeting deadlines

6. Support to customer decision

We emphasize that for customer loyalty, support to customer decision is a factor that 
we obtain by means of the declared information and through the result obtained in the multiple regression (which evidences its relevance).

Also using explanatory models, the most relevant factors for Global Satisfaction in a period of economic crisis, sorted by relevance, are:

7. Customer Trust

8. Correct carrying out of orders placed

9. Ability to solve problems

10. Support to customer decision

11. Friendliness and availability of employees

12. Price of banking products and services

13. Quality of the offer

We emphasize that, for global satisfaction, the price of products and services, ability to solve problems and support to customer decision are factors that were obtained through declarative information and as a result of multiple regression, which confirms their importance.

It has been scientifically demonstrated that trust is a very important factor for satisfaction and loyalty of bank customers. We may also refer that Customers Global Satisfaction is the main factor for customer loyalty.

The results obtained allow us to state that the trust in banks of Portuguese customers has decreased in recent years. However, even with the economic crisis and all the problems that occurred due to some banks failing in Portugal, customer trust in banks is not lower than the average trust in other sectors of the Portuguese economy.

Despite the decline in customer trust, the satisfaction level with the Portuguese banks is not significantly different from that in other European countries as stated in ECSI 2017 study.

With the results obtained in the questionnaire carried out in 2019 , we have compared the answers to the questions by means of 1 to 10 scales regarding trust, loyalty and overall satisfaction and compared them with those obtained in the questionnaire carried out in 2013.

The evaluation of all three variables has lowered, which confirms our view that something is changing, and trust, loyalty and overall satisfaction of bank customers is prone to decrease.

We have realized that trust was the variable that decreased the most in relation to 2007, having decreased by around $7.3 \%$, but the other two variables also decreased significantly, around $6.8 \%$ in the case of loyalty and $6.3 \%$ in the case of overall satisfaction. In relation to 2013 , the variable that decreased the most was loyalty, around $1.5 \%$, followed by confidence, around $1.5 \%$ and overall satisfaction, around $0.4 \%$.

The factors that may be contributing to decreasing customer satisfaction in regards their main bank are: the charging of commissions for services, low interest rates for financial investments, decreased human contact due to the use of new technologies and difficulty in obtaining credit.

In this study we have highlighted the importance given by clients to human contact in banking branches and the weak evaluation of trust in the future of national banking, which leads us to conclude that customers have a pessimistic perspective regards banks.

\section{FURTHER FUTURE STUDIES AND ANALYSES}

The results obtained in this study are mostly obtained through questionnaires applied to Portuguese banking customers. Further studies should imply extending the scope to other European countries, firstly Spain, in order to conduct a study on the Iberian Peninsula. This would allow us to test and eventually confirm our conclusions.

\section{REFERENCES}

Adamson, I.; Chan, K.M.; Handford, D. (2003). Relationship marketing: customer commitment and trust as a 
strategy for the smaller Hong Kong corporate banking sector. International Journal of Bank Marketing, vol. 21, n. 6/7, p. 347358.

Anderson, J. C; Gerbing, D.W. (1988). Structural Equation Modelling in Practice: A Review and Recommended Two-Step Approach. Psychological Bulletin, VoI.103, $\mathrm{N}^{\circ}$ 3, pp. 411-423.

Anderson, E.W.; Weitz, B. (1989). Determinants of continuity in conventional industrial channel dyads. Marketing Science 8 (4), p. 310-323.

Berry, L.L. (1995). Relationship marketing of services: growing interest, emerging perspectives. Journal of the Academy of Marketing Science, vol. 23, n. 4, p. 236-245

Berry, L.L. (2002). Relationship marketing of services: perspectives from 1983 and 2000. Journal of Relationship Marketing, vol. 1, n. 1.

Berry, L.L.; Zeithaml, V.A.; Parasuraman, A. (1985). Quality counts in services, too. Business Horizons, May-June, pp. 44-52.

Bhattacherjee, A. (2002). Individual Trust in Online Firms: Scale Development and Initial Test. Journal of Management Accounting Research, 19 (1), pp. 211-241.

Cabeças, António (2018). Trust of Portuguese customers in banks during the economic crisis period. 2100 Projects Association. Business Sustainability 2018 Congress presentation at Póvoa de Varzim, Portugal. Accepted for publication at The Proceedings of 2100 Projects Association Joint Conferences, ISSN: 2183-3060.

Cabeças, António; Santos, António Duarte (2019). A Confiança dos Clientes Portugueses na Evolução da Banca, Global Knowledge Academics Congress 2019 presentation, accepted for publication in Revista Internacional de Ciencias Sociales.
Coleman, James S. (1988). Social Capital in the Creation of Human Capital. American Journal of Sociology, vol. 94: 95-120.

Cooper, A.C.; Woo, C.Y.; Dunkelberg, W.C. (1988). Entrepreneurs' perceived chances for success. J. Business Vent. 3, 97 - 108.

Crosby, L.A.; Evans, K.R.; Cowles, D. (1990). Relationship Quality in Services Selling: An Interpersonal Influence Perspective. Journal of Marketing, 54 (July), 68-81.

Damásio, António R. (1994). Descartes' Error: Emotion, Reason, and the Human Brain. Grosset/Putnam, New York.

Damásio, António R.; Bechara, Antoine (2005). The somatic marker hypothesis: A neural theory of economic decision. Department of Neurology, University of Iowa, 200 Hawkins Drive, Iowa City, IA 52242, USA.

Davies, G.; Bank, J.H. (2002). A history of money: from ancient times to the present day. University of Wales Press, 2002.

Donário, Arlindo A.; Santos, R. Borges dos (2013) - O paradigma do homo economicus: consequências na construção do modelo económico e financeiro liberal. Centro de Análise Económica de Regulação Social. EDIUAL, Universidade Autónoma de Lisboa, Lisboa, 2013.

Dwyer, F.; Schurr, P; Oh, S. (1987). Developing buyer-seller relationships. Journal of Marketing, vol. 51, April, p. 11-27.

Ganesan, S. (1994). Determinants of LongTerm Orientation in Buyer-Seller Relationship. Journal of Marketing, 58: April, 1-19.

Guillemett, Yvan, Turner, David (2018). The Long View: Scenarios for the World Economy to 2060, OECD Economic Policy Papers, $n^{\circ}$ 22, July, OECD Publishing, Paris.

Hair Jr., J. F.; Anderson, R.E.; Tatham, R. L.; Black, W. C. (2005). Análise 
multivariada de dados. 5 ed., Porto Alegre: Bookman, 2005.

Hennig-Thurau, T.; Gwinner, K. P.; Gremler D. D. (2002). Understanding Relationship Marketing Outcomes: An Integration of Relational Benefits and Relationship Quality. Journal of Service Research, 1, 4(3), p. 230 247.

Johnston, J. (1984). Econometric Methods, McGraw-Hill, 3rd Edition, 1984.

Jones, T. O.; Sasser Jr., W.E. (1995). Why Satisfied Customers Defect. Harvard Business Review. 73 (6), pp. 88-99.

Kahneman, Daniel (2011). Thinking Fast and Slow. New York: Farrar, Straus and Giroux, pp. 281.

Kahneman, Daniel; Knetsch, Jack; Thaler, Richard (1991). Anomalies: The Endowment Effect, Loss Aversion, and Status Quo Bias. The Journal of Economic Perspectives, Vol. 5, No. 1. (Winter, 1991), pp. 193-206.

Kahneman, Daniel; Riis, Jason (2005). Living and Thinking about It: Two Perspectives on Life. In The Science of Well-Being, edited by N. Baylis, Felicia A. Huppert, and B. Keverne, 285-301. Oxford University Press, 2005.

Kahneman, Daniel; Tversky, Amos (1979). Prospect Theory: An Analysis of Decision under Risk. Econometrica, Volume 47, Issue 2 (Mar., 1979), 263-292.

Keynes, John Maynard (1936). The General Theory of Employment, Interest and Money. London. Macmillan, London, 1936 (reprint 2007).

Knight, Frank (1921). Risk, Uncertainty, and Profit. Harper, New York, 1921.

Kotler, P.; Armstrong, G. (1998). Princípios de Marketing. $7^{\text {a }}$ ed., Livros técnicos e Científicos Editora S.A., Rio de Janeiro.

Kotler, Philip (1998). Administração de Marketing: análise, planejamento, implementação e controle. $5^{\text {a }}$ edição, São Paulo: Atlas, 1998.
Kotler, Philip (2000). Administração de Marketing: A Edição do Novo Milénio. Prentice Hall. São Paulo.

Lancaster, Kelvin J. (1966). A New Approach to Consumer Theory. The Journal of Political Economy, Vol. 74, No. 2 (Apr., 1966), pp. 132-157. University of Chicago Press.

Lisack, Noemie, Sajedi, Rana, Thwaites, Gregory. Demographic trends and the real interest rate, Bank of England, Staff Working Paper No. 701, December.

Loewenstein, George; WEBER, Elke U.; HSEE, Christopher K.; WELCH, Ned (2001). Risk as Feelings. Psychological Bulletin, 127 (2), 26786.

Loewenstein, George; LERNER, Jennifer (2003). The Role of Affect in Decision Making, in Handbook of Affective Science, eds. Richard J. Dawson, Klaus R. Scherer and H. Hill Goldsmith, Oxford: Oxford University Press, 619-42.

Loewenstein, George; RICK, Scott (2008). The Role of Emotion in Economic Behavior, Risk Management and Decision Processes Center. The Wharton School, University of Pennsylvania, 2008.

Loewenstein, George; O'DONOGHUE, Ted (2004). Animal Spirits: Affective and Deliberative Processes in Economic Behavior. Working Paper, Carnegie Mellon.

Moorman, C.; Zaltman, G.; Deshpande, R. (1992). Relationships between providers and Users of market research: the dynamics of trust within and between organizations. Journal of Marketing Research, vol. 29.

Morgan, R. M.; Hunt, S. D. (1994). The commitment-trust theory of relationship marketing. Journal of Marketing, vol. 58, n. 3, p. 20-38.

Oliver, R. L. (1999). Whence consumer loyalty? Journal of Marketing, vol. 63, Special Issue, p.33-44, 1999. 
Reichheld, F. F. (1994). Loyalty and the renaissance of marketing. Marketing Management, vol. 2, n. 4, p. 10-17

Rich, M. (2000). The Direction of Marketing Relationships. Journal of Business \& Industrial Marketing, Vol. 15, No 2/3, pp. 170-179.

Samuelson, William; Zeckhauser, Richard (1988). Status Quo Bias in Decision Making. Journal of Risk and Uncertainty, I (1988), 7-59.

Sen, Amartya (1993). Positional Objectivity. Philosophy and Public Affairs, Vol. 22, N $\mathrm{N}^{\mathrm{a}} \mathrm{2}$ Spring, Princeton University Press, 1993.

Sen, Amartya (2004). How does culture matter? in Culture and Public Action, Edited by Vijayendra Rao and Michael Walton, Stanford University Press, Stanford, California, 2004.

Silva, J. M. Amado da (1991). Economia Industrial e Excesso de Capacidade. Coleção Estudo Geral Instituto de Novas Profissões.

Sirdeshmukh, D.; Singh, J.; Sabol, B. (2002). Consumer trust, value, and loyalty in relational exchanges. Journal of Marketing, vol. 66, January, p. 15-37.

Sivasubramanian, Srinivasan, Jacob, Lincy (2018). Retail banking trends for Australia, Infosys Limited External document, White Paper.

Thaler, Richard H. (1980). Toward a positive theory of consumer Choice. Journal of Economic Behavior and Organization 1 (1980), Cornefl University, Ithaca, NY, 39-60.

Tversky, Amos; Kahneman, Daniel (1981). The framing of decisions and the psychology of choice. Science, v.211, January 1981.

Yamagishi, Toshio; Cook, Karen; Watanabe, Motoki (1998). Uncertainty, trust and commitment formation in the United States and Japan. American Journal of Sociology, 104, 165-94. 